\title{
Papers
}

\section{Inhaled glucocorticoids versus leukotriene receptor antagonists as single agent asthma treatment: systematic review of current evidence}

Francine M Ducharme

\begin{abstract}
Objective To compare the safety and efficacy of anti-leukotrienes and inhaled glucocorticoids as monotherapy in people with asthma.

Design Systematic review of randomised controlled trials comparing anti-leukotrienes with inhaled glucocorticoids for 28 days or more in children and adults.

Main outcome measure Rate of exacerbations that required treatment with systemic glucocorticoids. Results 13 trials (12 in adults, one in children) met the inclusion criteria; all were in people with mild and moderate asthma. Leukotriene receptor antagonists were compared with inhaled glucocorticoids at a daily dose equivalent to 400-450 $\mu \mathrm{g}$ beclometasone dipropionate. Patients treated with leukotriene receptor antagonists were $60 \%$ more likely to suffer an exacerbation requiring systemic glucocorticoids (relative risk 1.6, 95\% confidence interval 1.2 to 2.2; number needed to treat 27, 13 to 81 ). A $130 \mathrm{ml}$ greater improvement $(80 \mathrm{ml}$ to $170 \mathrm{ml})$ in forced expiratory volume in one second and a $19 \mathrm{l} / \mathrm{min}$ greater increase (14 l to 24 l) in morning peak expiratory flow rate were noted in favour of inhaled glucocorticoids. Differences in favour of inhaled glucocorticoids were also observed for nocturnal awakenings, use of rescue $\beta_{2}$ agonists, and days without symptoms. Risk of side effects was no different between groups, but leukotriene receptor antagonists were associated a 2.5-fold increase risk of withdrawals due to poor asthma control (relative risk $2.5,1.8$ to 3.5$)$.

Conclusions Inhaled glucocorticoids doses equivalent to $400 \mu \mathrm{g} /$ day beclometasone are more effective than leukotriene receptor antagonists in the treatment of adults with mild or moderate asthma. There is insufficient evidence to conclude on the efficacy of anti-leukotrienes in children.
\end{abstract}

\section{Introduction}

Recent consensus statements on asthma advocate the treatment of airway inflammation for all patients except those with the mildest form of asthma. ${ }^{1-4}$ Inhaled glucocorticoids remain the cornerstone of asthma management. Although several drugs such as ketotifen, sodium cromoglycate, sodium nedocromil, and theophylline have anti-inflammatory properties, they are less effective than inhaled glucocorticoids. ${ }^{5}$ Anti-leukotrienes are a new class of anti-inflammatory drugs that interfere directly with leukotriene production (5-lipoxygenase inhibitors) or receptors (leukotriene receptors antagonists). ${ }^{6}$ Anti-leukotrienes are administered orally in a single or twice daily dose and seem to lack the adverse effects on growth, bone mineralisation, and adrenal axis associated with long term systemic glucocorticoid therapy.

While the 2002 Global Initiative for Asthma guidelines classify the role of anti-leukotrienes as still under investigation, ${ }^{4}$ several national guidelines advocate their use as adjunct therapy to inhaled glucocorticoids in people with moderate to severe persistent asthma or as alternative single agent management in those with mild asthma. ${ }^{1-3}$ In 2001, their sales in the United States almost equalled those of inhaled glucocorticoids, representing nearly $30 \%$ of the market share for antiasthmatic drugs, while they accounted for less than $10 \%$ of the market share in Canada and the United Kingdom (D Rhodes, IMS Health, personal communication, 2002). The variability among countries in the use of anti-leukotrienes attests to the confusion related to their relative efficacy and safety. In 2000 a systematic review of 10 randomised controlled trials, with complete data for only two trials, tentatively concluded that asthma control was better with inhaled glucocorticoids as single agents than with anti-leukotrienes. ${ }^{7}$ With the recent publication of several trials, ${ }^{8-14}$ it seems timely to update this Cochrane review and summarise the accumulated evidence on the safety and efficacy of anti-leukotrienes as single agent therapy.

\section{Methods}

Identification of trials

I searched Medline, Embase, CINAHL, and central (Cochrane controlled trials register) databases in January 2002 using the following MeSH, full text, and keyword terms: (leukotriene*, anti-leukotriene*, leukotriene* antagonist* or *lukast) and (inhaled steroids*, beclomet[h]asone*, fluticasone*, budesonide* or triamcinolone*). I checked bibliographies of identified trials and review articles and contacted the international
Departments of Paediatrics and of Epidemiology and Biostatistics, Montreal Children's Hospital, McGill University Health Centre, Montreal, Quebec, Canada

Francine M Ducharme associate professor Francine.ducharme@ muhc.mcgill.ca

bmj.com 2003;326:621 
headquarters of pharmaceutical companies that produce anti-leukotrienes and inhaled glucocorticoids.

Trials included were all randomised controlled trials that compared anti-leukotrienes with a stable dose of inhaled glucocorticoid for at least 28 days in adults and children aged 2 years and above. No additional antiasthmatic drugs were allowed, other than rescue short acting $\beta_{2}$ agonists and systemic glucocorticoids. Trials that documented only compliance or satisfaction or that tested higher than licensed doses of anti-leukotrienes were excluded. There was no restriction on language of publication.

\section{Data collection}

Two independent reviewers considered each potentially relevant trial for inclusion, assessed study quality using the Jadad score, ${ }^{15}$ and extracted data. Disagreements were resolved by consensus. Authors or sponsors of each included trial were contacted to verify the accuracy of the methodology and extracted data.

\section{Statistics}

The a priori specified primary outcome was the number of exacerbations requiring systemic glucocorticoids. Secondary outcomes included lung function, nocturnal awakenings, use of rescue $\beta_{2}$ agonist, adverse effects, and withdrawal rates.

Equivalence was assumed if the summary estimate of relative risk and its 95\% confidence limits were within $10 \%$ of the line indicating no difference. Differences between groups in event rates were reported as relative risk with the fixed effects model ${ }^{16}$ or, in case of heterogeneity, the random effects model. ${ }^{17}$ The weighted mean difference- -that is, the mean group difference of trials weighted by the inverse of the variance-was reported for continuous outcomes using the same unit of measure; otherwise, I used the standardised mean difference (SMD), reported as standard deviation units. Homogeneity of effect sizes among pooled studies was tested using the DerSimonian and Laird method, with 0.05 as the cut-off level for significance. ${ }^{17}$ Heterogeneity was explored using a priori subgroup analyses of the anti-leukotriene tested; the dose and inhaled glucocorticoid used; severity of asthma (mild, moderate); and patient age (child, adult). The difference in the magnitude of effect attributable to these subgroups was examined with the residual $\chi^{2}$ test for heterogeneity, based on the difference between the overall $\chi^{2}$ and the sum of the subgroups' $\chi^{2}$ test for heterogeneity. ${ }^{18}$ The comparison dose of inhaled glucocorticoids was converted to equivalents in $\mu \mathrm{g}$ of chlorofluorocarbon (CFC) propelled beclometasone dipropionate, where $1 \mu \mathrm{g}$ beclometasone equals $0.5 \mu \mathrm{g}$ fluticasone. ${ }^{1}$ Sensitivity analyses were conducted to investigate the effect on study results of quality of methods, publication bias, and funding bias-that is, expected bias in favour of the drug marketed by the sponsor(s). Funnel plots indicated presence of publication bias. ${ }^{19}$ The fail safe $\mathrm{N}$ test (the number of non-included trials with null results needed to negate current findings) assessed the robustness of the results. ${ }^{20}$ All estimates were reported with their 95\% confidence interval. The meta-analysis was performed with MetaView, version 4.1 (Cochrane Review Manager, Cochrane Collaboration, Oxford) and on EasyMA (Department of Clinical Pharmacology,
Lyons, France) for aggregation of trials with zero event rates-namely, for the main outcome.

\section{Results}

\section{Description of studies}

The search strategy yielded 451 citations (fig 1). Thirteen trials met the inclusion criteria, of which five were new trials ${ }^{9-13}$ not included in the previous review. Two trials included in the previous analysis failed to meet the inclusion criteria based on new information (fig 1). ${ }^{21}{ }^{22}$ At the time of this report, nine trials were published in full text ${ }^{8-142324}$ and the four remaining were available in abstract form only (table 1). ${ }^{25-28}$

All trials had a parallel group design and 10 were of high methodological quality (table 2). Confirmation of methods and data extraction was obtained from the authors of 12 trials, including voluntary disclosure of data for the four unpublished studies. Double blinding was reported by all but three trials, which used an open label design. ${ }^{12}{ }^{1326}$ Most trials reported appropriate randomisation methods; two trials reported insufficient details ${ }^{12}$ or inappropriate randomisation. ${ }^{14}$

The studies were relatively homogeneous in the age and sex of participants, daily dose of inhaled glucocorticoids tested (that is, equivalent to $400 \mu \mathrm{g}$ CFC beclometasone), and intention to treat analysis. Only one trial dealt with children..$^{13}$ Four trials focused on people with mild asthma (baseline forced expiratory flow in one second $\geqslant 80 \%$ of predicted), ${ }^{12} 132627$ eight trials comprised patients with moderate obstruction, ${ }^{8-11} 23-2528$ and one trial failed to report asthma severity. ${ }^{14}$ One study that tested two different preparations of inhaled glucocorticoid is referred hereafter as two studies. ${ }^{26}$ To prevent over-representation of the anti-leukotriene group used as comparator twice, the sample size of montelukast group was reduced by half for the purpose of the analysis.

Exacerbations requiring systemic glucocorticoids Patients treated with leukotriene receptor antagonists were $60 \%$ more likely to experience an exacerbation

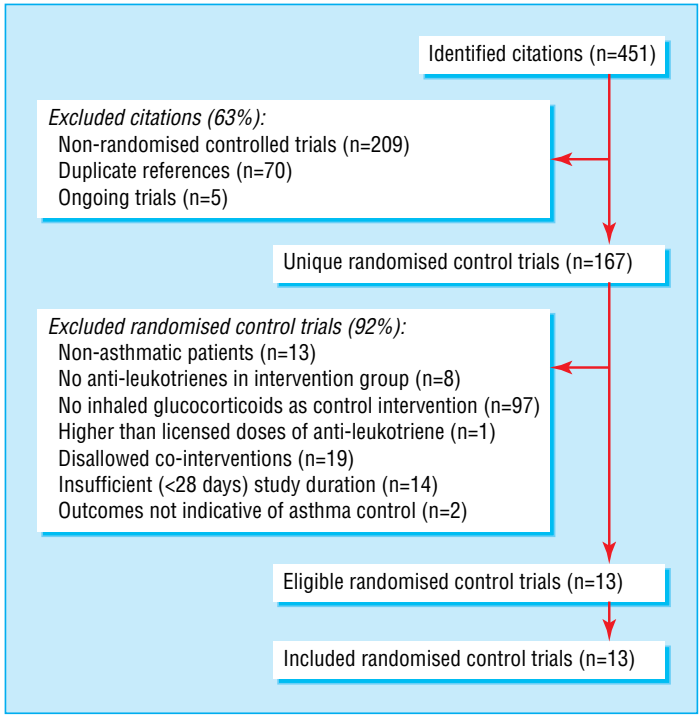

Fig 1 Selection process of eligible randomised controlled trials from all identified citations 
Table 1 Characteristics of included trials

\begin{tabular}{|c|c|c|c|c|c|c|c|c|c|c|c|c|c|c|c|c|}
\hline \multirow[b]{2}{*}{ Trials } & \multirow[b]{2}{*}{$\begin{array}{c}\text { No of } \\
\text { patients }\end{array}$} & \multirow[b]{2}{*}{$\begin{array}{l}\text { Publication } \\
\text { status }\end{array}$} & \multirow{2}{*}{$\begin{array}{c}\text { Mean } \\
\text { age } \\
\text { (years) }\end{array}$} & \multirow[b]{2}{*}{$\begin{array}{l}\% \\
\text { Male }\end{array}$} & \multirow{2}{*}{$\begin{array}{l}\text { Baseline }^{\text {FEV }} \\
\text { (mean \% } \\
\text { predicted) }\end{array}$} & \multirow[b]{2}{*}{$\begin{array}{c}\% \\
\text { Atopy }\end{array}$} & \multirow{2}{*}{$\begin{array}{l}\text { Run in (wash } \\
\text { out for } \\
\text { extension } \\
\text { studies) } \\
\text { before } \\
\text { randomisation }\end{array}$} & \multicolumn{2}{|c|}{ Anti-leukotrienes } & \multicolumn{2}{|c|}{ Inhaled glucocorticoids } & \multirow{2}{*}{$\begin{array}{c}\text { Duration } \\
\text { of } \\
\text { treatment } \\
\text { (weeks) }\end{array}$} & \multirow{2}{*}{$\begin{array}{c}\text { Intention } \\
\text { to treat } \\
\text { analyses }\end{array}$} & \multicolumn{2}{|c|}{ Reported outcomes } & \multirow[b]{2}{*}{ Fundingt } \\
\hline & & & & & & & & Drug & Dose & Drug $^{*}$ & $\begin{array}{c}\text { Control group } \\
\text { dose }\end{array}$ & & & $\begin{array}{l}\text { systemic } \\
\text { steroids }\end{array}$ & $\mathrm{FEV}_{1}$ & \\
\hline Baumgartner $^{25}$ & 627 & - & 36 & 35 & 68 & 68 & 2 weeks & Montelukast & $\begin{array}{c}10 \mathrm{mg} \\
\text { once daily }\end{array}$ & $\begin{array}{c}\text { Beclometasone } \\
\text { dipropionate }\end{array}$ & 400 mg/day & 6 & + & + & + & $\mathrm{AL}$ \\
\hline Bleecker ${ }^{11}$ & 451 & + & 31 & 50 & 68 & 45 & 1-2 weeks & Zafirlukast & $\begin{array}{c}20 \mathrm{mg} \\
\text { twice daily }\end{array}$ & $\begin{array}{l}\text { Fluticasone } \\
\text { propionate }\end{array}$ & $\begin{array}{c}100 \mathrm{mg} \text { twice } \\
\text { daily }\end{array}$ & 12 & + & + & + & ICS \\
\hline Busse $^{8}$ & 533 & + & 35 & 45 & 65 & NR & 1-2 weeks & Montelukast & $\begin{array}{c}10 \mathrm{mg} \\
\text { once daily }\end{array}$ & $\begin{array}{l}\text { Fluticasone } \\
\text { propionate }\end{array}$ & $\begin{array}{c}100 \mathrm{mg} \text { twice } \\
\text { daily }\end{array}$ & 24 & + & + & + & ICS \\
\hline Busse $^{9}$ & 224 & + & 32 & 50 & 68 & 32 & 1-2 weeks & Zafirlukast & $\begin{array}{c}20 \mathrm{mg} \\
\text { twice daily }\end{array}$ & $\begin{array}{l}\text { Fluticasone } \\
\text { propionate }\end{array}$ & $\begin{array}{c}100 \mathrm{mg} \text { twice } \\
\text { daily }\end{array}$ & 12 & + & + & + & ICS \\
\hline \multirow[t]{2}{*}{ Hughes $^{26}$} & 71 & - & 30 & 48 & 84 & 87 & 2 weeks & Montelukast & $\begin{array}{c}10 \mathrm{mg} \\
\text { once daily }\end{array}$ & Budesonide & 400 mg/day & 4 & + & + & + & ICS \\
\hline & & & & & & & & Montelukast & $\begin{array}{c}10 \mathrm{mg} \\
\text { once daily }\end{array}$ & $\begin{array}{l}\text { Fluticasone } \\
\text { propionate }\end{array}$ & $200 \mathrm{mg} / \mathrm{day}$ & 4 & + & + & + & ICS \\
\hline $\mathrm{Kim}^{10}$ & 437 & + & 34 & 40 & 74 & 57 & 1 week & Zafirlukast & $\begin{array}{c}20 \mathrm{mg} \\
\text { twice daily }\end{array}$ & $\begin{array}{l}\text { Fluticasone } \\
\text { propionate }\end{array}$ & $\begin{array}{l}100 \mathrm{mg} \text { twice } \\
\text { daily }\end{array}$ & 6 & + & + & + & ICS \\
\hline Laitinen $^{27}$ & 481 & - & 38 & 51 & 80 & 54 & NR & Zafirlukast & $\begin{array}{c}20 \mathrm{mg} \\
\text { twice daily }\end{array}$ & $\begin{array}{l}\text { Beclometasone } \\
\text { dipropionate }\end{array}$ & $\begin{array}{l}200-250 \mathrm{mg} \\
\text { twice daily }\end{array}$ & 6 & - & - & + & AL \\
\hline Laviolette $^{23}$ & 401 & + & 39 & 50 & 72 & 74 & 4 weeks & Montelukast & $\begin{array}{c}10 \mathrm{mg} \\
\text { once daily }\end{array}$ & $\begin{array}{c}\text { Beclometasone } \\
\text { dipropionate }\end{array}$ & $\begin{array}{l}200 \mathrm{mg} \text { twice } \\
\text { daily }\end{array}$ & 16 & + & + & + & AL \\
\hline Malmstrom ${ }^{24}$ & 638 & + & 35 & 38 & 65 & 62 & 2 & Montelukast & $\begin{array}{c}10 \mathrm{mg} \\
\text { once daily }\end{array}$ & $\begin{array}{l}\text { Beclometasone } \\
\text { dipropionate }\end{array}$ & $\begin{array}{l}200 \mathrm{mg} \text { twice } \\
\text { daily }\end{array}$ & 12 & + & - & + & AL \\
\hline Maspero $^{13}$ & 124 & + & 10 & 60 & 82 & 65 & None & Montelukast & 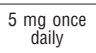 & $\begin{array}{c}\text { Beclometasone } \\
\text { dipropionate }\end{array}$ & $\begin{array}{l}100 \mathrm{mg} \text { three } \\
\text { times a day }\end{array}$ & 24 & + & + & + & AL \\
\hline Skalky ${ }^{28}$ & 666 & - & 34 & 47 & 66 & 90 & 3 weeks & Montelukast & $\begin{array}{c}10 \mathrm{mg} \\
\text { once daily }\end{array}$ & $\begin{array}{c}\text { Beclometasone } \\
\text { dipropionate }\end{array}$ & $\begin{array}{l}200 \mathrm{mg} \text { twice } \\
\text { daily }\end{array}$ & 6 & + & + & + & AL \\
\hline Williams $A^{14}$ & 436 & + & 37 & 38 & NR & 63 & None & Montelukast & $\begin{array}{c}10 \mathrm{mg} \\
\text { once daily }\end{array}$ & $\begin{array}{l}\text { Beclometasone } \\
\text { dipropionate }\end{array}$ & $\begin{array}{c}200 \mathrm{mg} \text { twice } \\
\text { daily }\end{array}$ & 37 & + & + & + & $\mathrm{AL}$ \\
\hline Yamauchi' ${ }^{12}$ & 20 & + & 41 & 65 & 92 & 60 & NR & Pranlukast & $\begin{array}{c}450 \mathrm{mg} \\
\text { once daily }\end{array}$ & $\begin{array}{l}\text { Beclometasone } \\
\text { dipropionate }\end{array}$ & 400 mg/day & 4 & NR & - & - & - \\
\hline
\end{tabular}

$\mathrm{NR}=$ not reported

*Beclometasone and fluticasone were propelled by chlorofluorocarbon (CFC); no trial used hydrofluorocarbon (HFA) as propellant.

†ICS if funded by manufacturers of inhaled corticosteroids; AL if funded by manufacturers of anti-leukotrienes; "-" if funding was independent from drug manufacturers.

requiring systemic glucocorticoids than those treated with inhaled glucocorticoids ( 11 trials; relative risk 1.6, $95 \%$ confidence interval 1.2 to 2.2 ; random effects model) (fig 2). Twenty seven people (13 to 81 ) would need to be treated with inhaled glucocorticoids instead of leukotriene receptor antagonists to prevent an exacerbation requiring systemic glucocorticoids. The funnel plots indicated no evidence of systematic bias (intercept $0.56,-0.18$ to 1.29 ). The fail safe $\mathrm{N}$ was 59 trials.

\section{Source of heterogeneity}

No a priori factor was a major determinant of the magnitude of effect. The leukotriene receptor antagonist $\left(\chi^{2}\right.$ test $\left.=1.86, \mathrm{df}=1, \mathrm{P}>0.10\right)$, the inhaled glucocorticoid preparation used $(1.86, \mathrm{df}=1, \mathrm{P}>0.10)$, and the baseline severity $(2.52, \mathrm{df}=1, \mathrm{P}>0.10)$ failed to explain the difference among studies in the magnitude of effect. ${ }^{13}$ There was no group difference in the only paediatric trial (relative risk $0.78,0.32$ to 1.85 ). Because all trials contributing data to this outcome used doses equivalent to $400 \mu \mathrm{g} /$ day $\mathrm{CFC}$ beclometasone, the strength of the inhaled glucocorticoids could not explain the observed heterogeneity. Sensitivity analyses did not show any significant influences of quality of methods, intention to treat analysis, publication status, or funding source.

\section{Secondary outcomes}

There were significant group differences in favour of inhaled glucocorticoids for the several outcomes at all points in time. Within six weeks of treatment,

Table 2 Methodological quality of included trials

\begin{tabular}{|c|c|c|c|c|c|c|c|}
\hline \multirow[b]{2}{*}{ Trials } & \multirow[b]{2}{*}{ Randomisation* } & \multirow[b]{2}{*}{ Blinding† } & \multirow[b]{2}{*}{$\begin{array}{l}\text { Withdrawals/ } \\
\text { dropoutsł }\end{array}$} & \multirow[b]{2}{*}{ Jadad score ${ }^{15}$} & \multirow[b]{2}{*}{$\begin{array}{l}\text { Methods } \\
\text { confirmed }\end{array}$} & \multicolumn{2}{|c|}{ Withdrawals } \\
\hline & & & & & & $\begin{array}{c}\text { Anti-leukotrienes } \\
(\%)\end{array}$ & $\begin{array}{c}\text { Inhaled } \\
\text { glucocorticoids (\%) }\end{array}$ \\
\hline Baumgartner $^{25}$ & 2 & 2 & 1 & 5 & + & 7 & 6 \\
\hline Bleecker ${ }^{11}$ & 2 & 2 & 1 & 5 & + & 23 & 13 \\
\hline Busse $^{8}$ & 2 & 2 & 1 & 5 & + & 29 & 28 \\
\hline Busse $^{9}$ & 2 & 2 & 1 & 5 & + & 19 & 14 \\
\hline Hughes $^{26}$ & 2 & 0 & 1 & 3 & + & 0 & $4 \pi$ \\
\hline $\mathrm{Kim}^{10}$ & 2 & 2 & 1 & 5 & + & 21 & 9 \\
\hline Laitinen $^{27}$ & 2 & 2 & 1 & 5 & + & 9 & 8 \\
\hline Laviolette $^{23}$ & 2 & 2 & 1 & 5 & + & 21 & 11 \\
\hline Malmstrom ${ }^{24}$ & 2 & 2 & 1 & 5 & + & 7 & 9 \\
\hline Maspero $^{13}$ & 2 & 0 & 1 & 3 & + & 6 & 7 \\
\hline Skalky ${ }^{28}$ & 2 & 2 & 1 & 3 & + & 3 & 4 \\
\hline Williams $A^{14}$ & $1 \S$ & 2 & 1 & 4 & + & 12 & 14 \\
\hline Yamauchi $^{12}$ & 1 & 0 & 0 & 1 & - & NR & NR \\
\hline
\end{tabular}

$\mathrm{NR}=$ not reported.

${ }^{*} 0=$ not randomised; $1=$ method not described or suboptimal; $2=$ appropriate method

$\dagger 0=$ no blinding; $1=$ double blind, means of blinding not reported; $2=$ double blind, means of blinding appropriate.

$\ddagger 0=$ not described for each group; $1=$ described by group.

§Patients randomised before initial study without second randomisation procedure before extension study despite $51 \%$ dropout rate from initial study.

IIn this study one group received budesonide and there were no withdrawals, the other group received fluticasone and $4 \%$ withdrew. 


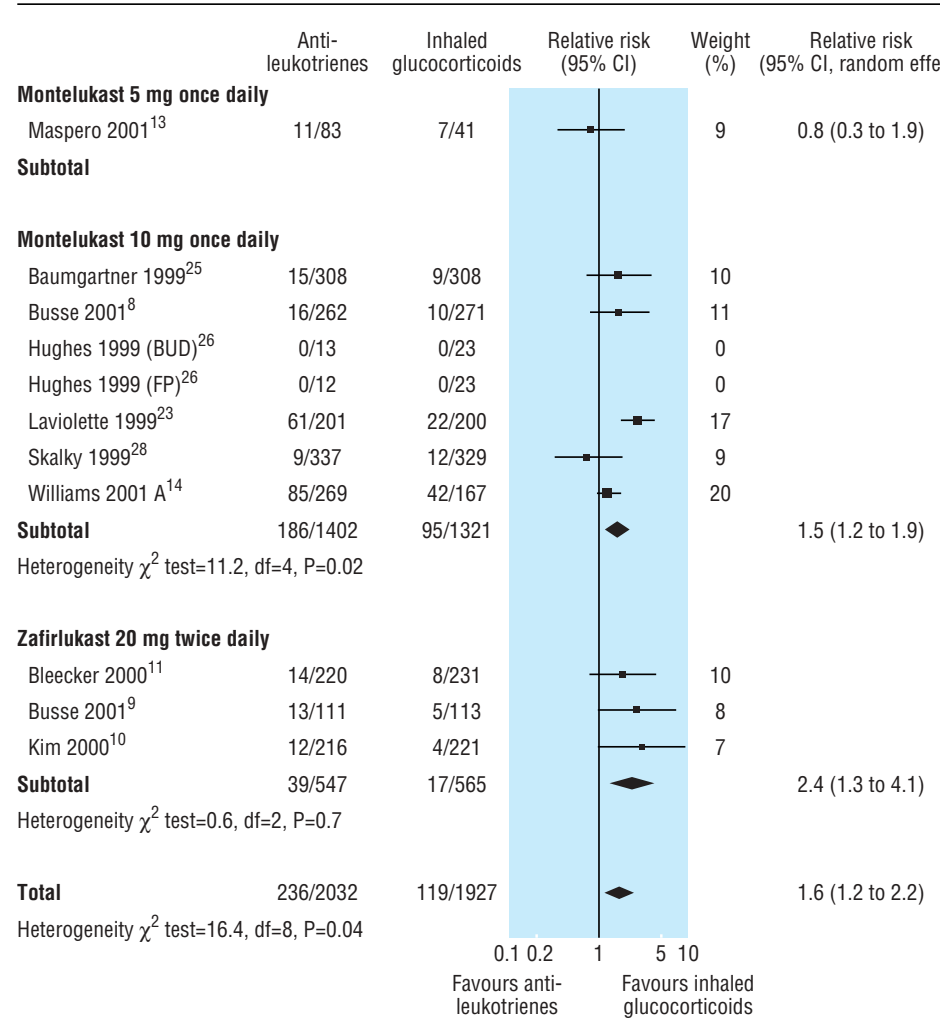

Fig 2 Pooled relative risk of patients experiencing at least one exacerbation requiring systemic glucocorticoids (one count per patient) comparing leukotriene receptor antagonists with inhaled glucocorticoids. Trials stratified according to dose and leukotriene receptor antagonists used. Hughes' trial tested two inhaled glucocorticoid preparations: $400 \mu \mathrm{g}$ budesonide (BUD) and $200 \mu \mathrm{g}$ fluticasone propionate (FP) against montelukast. To prevent over-representation of anti-leukotriene group, sample size of 25 of montelukast group was reduced by half for analysis. $\chi^{2}$ test for heterogeneity was considered significant if $P<0.10$

compared with patients in the anti-leukotriene group, patients treated with inhaled glucocorticoids experienced a significantly greater improvement from baseline in forced expiratory flow in one second (eight trials; weighted mean difference $130 \mathrm{ml}, 80 \mathrm{ml}$ to 170 $\mathrm{ml}$; random effects model) and morning peak expiratory flow (seven trials; $19 \mathrm{l} / \mathrm{min} ; 14 \mathrm{l}$ to $25 \mathrm{l}$ ); fewer nocturnal awakenings a week (five trials; -0.56 , -0.28 to -0.77 ); less rescue use of $\beta_{2}$ agonists (six trials; $-0.78,-0.55$ to -1.00 puffs a day); and fewer days with symptoms (three trials; $-9 \%,-5 \%$ to $-13 \%$ ).

Anti-leukotriene treatment was associated with an increased risk of withdrawal because of poor asthma control (12 trials; relative risk 2.5, 1.8 to 3.5). There was no group difference in the number of patients who experienced "any adverse effects" (11 trials; 1.0, 0.9 to 1.1). There were no differences between the groups in increase in liver enzyme activity, headache, oral candidiasis, nausea, and death.

\section{Discussion}

In adults with mild to moderate chronic asthma the risk of exacerbations requiring systemic glucocorticoids was $60 \%$ higher with daily oral leukotriene receptor antagonists than with doses of inhaled glucocorticoid equivalent to $400 \mu \mathrm{g}$ /day inhaled beclometasone. Interestingly, the effect was not influenced by the anti-leukotriene or inhaled corticosteroid used, disease severity, quality of methods, intention to treat analysis, publication status, or funding source. The 24 week trial in children with mild asthma showed no group difference, ${ }^{13}$ but the results failed to meet the a priori definition of equivalence. The small number of trials precluded the use of meta-regression analysis so the individual effect of these factors could not be identified..$^{29}$

Inhaled glucocorticoids at doses equivalent to $400 \mu \mathrm{g} /$ day beclometasone dipropionate were more effective than leukotriene receptor antagonists in improving spirometry; increasing the percentage of days without symptoms; and reducing night awakenings and rescue use of $\beta_{2}$ agonists. The higher rate of withdrawals in the anti-leukotriene group because of poor asthma control supported the above findings. Thus, all outcomes clearly favoured the use of inhaled glucocorticoids over leukotriene receptor antagonists with little heterogeneity; results were relatively similar among trials regardless of the leukotriene receptor antagonist and inhaled steroid used. When heterogeneity was identified, the anti-leukotriene used failed to explain the variation among trial results. Moreover, the superiority of inhaled glucocorticoids was evident rapidly (within four to six weeks) and persisted for up to 37 weeks. The exact glucocorticoids dose equivalence of leukotriene receptor antagonists remains to be determined.

Leukotriene receptor antagonists seem to be safe; the risk of overall adverse effects was similar in both groups, meeting our a priori definition of equivalence. No rare adverse effects, such as Churg-Strauss syndrome, were not reported. Adverse effects typically associated with inhaled glucocorticoids (such as suppression of growth, osteopenia, and adrenal suppression) were not measured, preventing a fair comparison of the safety profile on long term use.

This review summarises the best evidence available (in January 2002) for the use of anti-leukotrienes as monotherapy. In combination with the recent review on their use as additional treatment to inhaled glucocorticoids ${ }^{30}$ this completes the assessment of their role in treatment of asthma. The identification of unpublished trials from producers of anti-leukotrienes and inhaled glucocorticoids argues against important selection bias. A fail safe $\mathrm{N}$ of 59 trials supports the robustness of this review - that is, 59 additional trials with null results would be needed to reverse the current findings. With only one paediatric trial, however, the results should be generalised to children with caution.

In adults with mild to moderate asthma, leukotriene receptor antagonists are safe but less effective than low dose inhaled glucocorticoids in preventing asthma exacerbations and maintaining asthma control. Although the exact dose equivalence of leukotriene receptor antagonists remains elusive, $400 \mu \mathrm{g}$ beclometasone dipropionate or $200 \mu \mathrm{g}$ fluticasone propionate are clearly superior to $10 \mathrm{mg}$ /day montelukast or 20 $\mathrm{mg}$ zafirlukast twice daily. There is insufficient evidence to make any firm conclusions about the use of leukotriene receptor antagonists as monotherapy in children. At present, the scientific evidence does not support the substitution of leukotriene receptor antagonists for inhaled glucocorticoids, which remain first line therapy for asthma. 


\section{What is already known on this topic}

In 2000 a Cochrane systematic review tentatively concluded that control of asthma was better in patients treated with inhaled glucocorticoids as single agents than with anti-leukotrienes

The 2002 Global Initiative for Asthma guidelines still classify the role of anti-leukotrienes as "under investigation"

\section{What this study adds}

Anti-leukotrienes as single agent are less effective than low doses of inhaled glucocorticoids for patients with mild and moderate persistent asthma

I acknowledge the collaboration of Christopher Miller and Susan Shaffer (AstraZeneca, USA), Theodore F Reiss and G P Noonan (Merck Frosst, USA), and Shailesh Patel and Rob Pearson (GlaxoSmithKline, UK), who confirmed the methods and data extraction and voluntarily disclosed additional data. I thank Giselle Hicks for her participation in the identification of eligible trials, assessment of methods and data extraction, and data entry. I am indebted to the Cochrane Airways Review Group-namely, Toby Lasserson and Karen Blackhall, for the literature search and ongoing support, and Paul Jones and Christopher Cates, for their constructive comments.

Contributors: FMD is the guarantor of the paper. She conceived the protocol, requested the literature search, reviewed all citations for relevance, reviewed all included trials for methods and data extraction, corresponded with the authors or pharmaceutical companies to solicit their collaboration, verified all references, description of studies and data entry, analysed and interpreted the results of the meta-analysis and wrote the manuscript. From November 1999 to February 2000, Giselle Hicks reviewed several citations for relevance, extracted methods and data, and entered data for several trials.

Funding: Senior salary award of the Fonds de la Recherche en Santé du Québec. No research funding was available for the review. The guarantor accepts full responsibility for the conduct of the study, had access to the data, and controlled the decision to publish.

Competing interests: The author has received travel support, research funds, and fees for speaking from AstraZeneca, producer of zafirlukast; Merck Frosst, producer of montelukast; and GlaxoSmithKline, producer of inhaled glucocorticoid preparations with which leukotriene receptor antagonists were compared.

1 National Asthma Education and Prevention Program. NAEPP expert panel report guidelines for the diagnosis and management of asthma. 2002 : Bethesda, MD: National Heart, Lung and Blood Institute, 2002 (NIH Publication 02-5075). www.nhlbi.nih.gov/guidelines/asthma/index.htm

2 Boulet LP, Bai TR, Becker A, Berube D, Beveridge R, Bowie DM, et al. What is new since the last (1999) Canadian Asthma Consensus Guidelines? Can Respir J 2001;8(suppl A):5-27a.

3 The British guidelines on asthma management. Thorax 1997;52(suppl):S1-21

4 Global Initiative for Asthma. Global strategy for asthma management and prevention. Bethesda, MD: National Heart, Lung and Blood Institute, 2002 (NIH Publication 02-3659). www.ginasthma.com/

5 Spahn JD, Leung DYM. The role of glucocorticoids in the management of asthma. Allergy Asthma Proc 1996;17:341-50.

6 Drazen JM, Israel E, O'Byrne PM. Treatment of asthma with drugs modifying the leukotriene pathway. New Engl J Med 1999;340:197-206.
7 Ducharme FM, Hicks G. Anti-leukotriene agents compared to inhaled corticosteroids in the management of recurrent and/or chronic asthma. Cochrane Database Syst Rev 2000;(3):CD002314.

8 Busse W, Raphael GD, Galant S, Kalberg C, Goode-Sellers S, Srebo S, et al. Low-dose fluticasone propionate compared with montelukast for first-line treatment of persistent asthma: a randomized clinical trial. $J$ Allergy Clin Immunol 2001;107:461-8.

9 Busse W, Wolfe J, Storms W, Srebo S, Edwards L, Johnson M, et al. Fluticasone propionate compared with zafirlukast in controlling persistent asthma: a randomized double-blind, placebo-controlled trial. J Fam Pract 2001:50:595-602.

10 Kim KT, Ginchansky EJ, Friedman BF, Srebo S, Pepsin PJ, Edwards L, et al. Fluticasone propionate versus zafirlukast: effect in patients previously al. Fluticasone propionate versus zafirlukast: effect in patients previously
receiving inhaled corticosteroid therapy. Ann Allergy Asthma Immunol receiving inhaled

11 Bleecker ER, Welch MJ, Weinstein SF, Kalberg C, Johnson M, Edwards L, et al. Low-dose inhaled fluticasone propionate versus oral zafirlukast in the treatment of persistent asthma. J Allergy Clin Immunol 2000;105:1123-9.

12 Yamauchi K, Tanifuji Y, Pan LH, Yoshida T, Sakurai S, Goto S, et al. Effects of pranlukast, a leukotriene receptor antagonist, on airway inflammation in mild asthmatics. J Asthma 2001;38:51-7.

13 Maspero JF, Duenas-Meza E, Volovitz B, Pinacho Daza C, Kosa L, Vrijens $\mathrm{F}$, et al. Oral montelukast versus inhaled beclomethasone in 6- to 11-year-old childen 11-year-old children with asthma: results of an open-label extension study evaluating long-term safety, satisfa

14 Williams B, Noonan G, Reiss TF, Knorr B, Guerra J, White R, et al. Long4 Williams B, Noonan G, Reiss TF, Knorr B, Guerra J, White R, et al. Long-
term asthma control with oral montelukast and inhaled beclomethasone for adults and children 6 years and older. Clin Exp Allergy 2001;31:845-54

15 Jadad AR, Moore RA, Carroll D, Jenkinson C, Reynolds DJ, Gavaghan DJ, et al. Assessing the quality of reports of randomized controlled trials: is blinding necessary? Control Clin Trials 1996;17:1-12.

16 Greenland S, Robins JM. Estimation of a common effect parameter from sparse follow-up data. Biometrics 1985;41:55-68.

17 DerSimonian R, Laird N. Meta-analysis in clinical trials. Control Clin Trials 1986:7:177-88.

18 Deeks JJ, Altman DG, Bradburn MJ. Statistical methods for examining heterogeneity and combining results from several studies in metaanalysis. In: Egger M, Smith GD, Altman DG, eds. Systematic reviews in health care: meta-analysis in context. 2nd ed. London: BMJ Publishing, 2001:285-312.

19 Egger M, Smith GD, Schneider M, Minder C. Bias in meta-analysis detected by a simple, graphical test. BMJ 1997;315:629-34.

20 Gleser LJ, Olkin I. Models for estimating the number of unpublished studies. Stat Med 1996;15:2493-507.

21 Korenblat P, Chervinsky P, Wenzel S, Faiferman I, Bakst A. Pranlukast (Ultair) reduce health care utilization and improves quality of life in alds patients with mild-to moderate asthma. Am J Respir Crit Cife inged 1998;157:A411

22 Williams B, Noonan G, Reiss TF, Knorr B, Guerra J, White R, et al. Longterm asthma control with oral montelukast and inhaled beclomethasone for adults and children 6 years and older. Clin Exp Allergy 2001;31:845-54

23 Laviolette M, Malmstrom K, Lu S, Chervinsky P, Pujet JC, Peszek I, et al. Montelukast added to inhaled beclomethasone in treatment of asthma. Am J Respir Crit Care Med 1999;160:1862-8.

24 Malmstrom K, Rodriguez-Gomez G, Guerra J, Villaran C, Pineiro A, Wei LX, et al. Oral montelukast, inhaled beclomethasone, and placebo for chronic asthma. A randomized, controlled trial. Montelukast/ beclomethasone study group. Ann Intern Med 1999;130:487-95.

25 Baumgartner RA, Polis A, Angner R, Bird S, Reiss TF. Comparison between montelukast and inhaled beclomethasone therapy in chronic asthma. Am J Resp Crit Care Med 1999;159:A640.

26 Hughes GL, Edelman JM, Turpin J, Liss C, Weeks K, Rand C. Randomized, open-label pilot study comparing the effects of montelukast sodium tablets, fluticasone aerosol inhaler, and budesonide dry powder inhaler on asthma control in mild asthmatics. Am J Resp Crit Care Med 1999;159:A641.

27 Laitinen LA, Naya IP, Binks S, Harris A. Comparative efficacy of zafirlukast and low dose steroids in asthmatics on prn beta2-agonists. Eur Respir J 1997;10:419-20.

28 Skalky CS, Edelman J, Polis A, Bird S, Gormley C, Israel E. Montelukast sodium (MK) compared to inhaled beclomethasone dipropionate (BD) in adults asthmatics: a randomized clinical trial. J Allergy Clin Immunol in adults asthm

29 Thompson SG, Sharp SJ. Explaining heterogeneity in meta-analysis: a comparison of methods. Stat Med 1999;18:2693-708.

30 Ducharme FM. Anti-leukotrienes as add-on therapy to inhaled glucocorticoids in patients with asthma: systematic review of current evidence. BMJ 2002;324:1545-52.

(Accepted 29 January 2003) 